\title{
The Earth Mapping Resources Initiative (Earth MRI): Mapping the Nation's Critical Mineral Resources
}

\section{What is Earth MRI?}

The Earth Mapping Resources Initiative (Earth MRI; formerly known as 3DEEP) is planned as a partnership between the U.S. Geological Survey (USGS), the Association of American State Geologists (AASG), and other Federal, State, and private-sector organizations. The goal of the effort is to improve our knowledge of the geologic framework in the United States and to identify areas that have the potential to contain undiscovered critical mineral resources. Enhancement of our domestic mineral supply will decrease our reliance on foreign sources of minerals that are fundamental to the Nation's security and economy.

The intent of Earth MRI is to leverage the USGS's existing relationships with States and the private sector to conduct state-of-the-art geologic mapping and airborne geophysical and topographic (lidar) surveys. Analyses of these datasets could point to potential buried critical mineral deposits.

\section{Why is Earth MRI Needed?}

The motivations for starting Earth MRI and the potential returns on investment follow:

- The United States is 100-percent dependent on imports for 21 critical mineral commodities and is at least 50-percent dependent on imports for another 28 critical mineral commodities (Lederer and McCullough, 2018).
- Undiscovered deposits of at least some of these critical and strategic minerals almost certainly exist in the United States, but mineral exploration by the private sector is hampered by the lack of modern geological, geophysical, and topographic data. In contrast, governments of other countries provide such datasets to the private sector.

- Studies in Australia and Canada have reported that investments by their federal governments in these basic geologic and geophysical datasets can be expected to lead to investments five times as large by the private sector (Duke, 2010; ACIL Allen Consulting, 2015).

- Studies sponsored by Earth MRI will aim to identify areas with potential for undiscovered critical mineral deposits that could reduce U.S. mineral import dependence, thereby strengthening national security, creating jobs within the private sector, and generating ancillary economic and social benefits.

- Information acquired through this initiative could also advance our understanding of other economically valuable mineral resources (such as copper, zinc, gold, and industrial minerals), energy and groundwater resources, and geologic hazards (fig. 1). It could help address other pressing societal issues in need of detailed geoscience information, such as identifying earth resources needed for revitalizing the Nation's roads, bridges, and other infrastructure systems.

\section{First Steps in Implementing Earth MRI}

The USGS Mineral Resources Program will manage Earth MRI. Initial funding will focus on the highest priority regions of the United States. The proposed first steps are listed below:

- Forge cost-shared cooperative agreements between the USGS and State geological surveys and provide funding to State surveys for new geologic mapping and for data preservation through the USGS National Cooperative Geologic Mapping Program and National Geological and Geophysical Data Preservation Program, respectively.

- Establish contracts with private industry to conduct geophysical and lidar surveys.

- Offer partnership opportunities for collecting lidar data under the USGS 3D Elevation Program broad agency announcement.

- In fiscal year (FY) 2019, focus new data collection on areas potentially containing rare earth element mineral deposits. In FY20 and beyond, target new priority critical mineral resources and identify new focus areas for integrated studies.

- Complete a preliminary national-scale data inventory of geologic framework and minerals data to define focus areas to guide future data collection efforts.

- Design and implement a digital geospatial platform to deliver the new data to the public. This platform will allow the user to access the USGS's authoritative topographic, geologic, geophysical, geochemical, and mineral deposit information within a single portal.

- Collaborate with industry, State, and Tribal entities to identify their future science needs. 


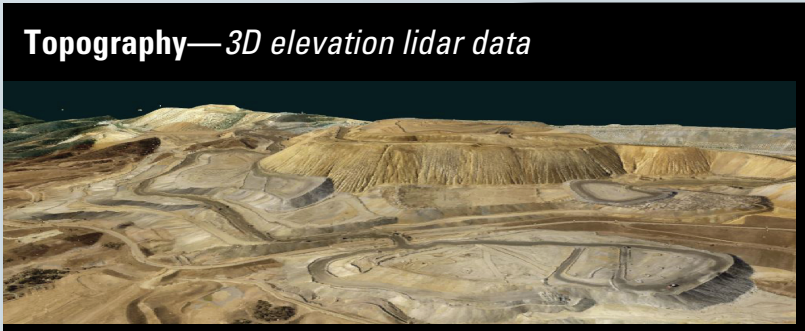

\section{Geology-USGS and State geological survey maps}

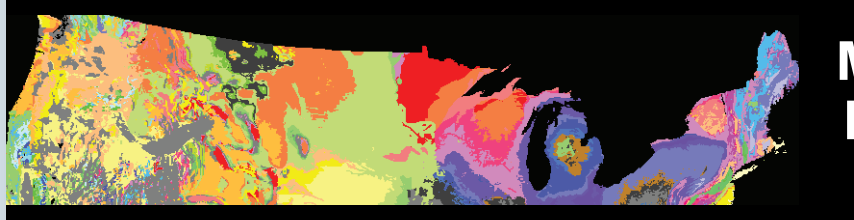

Geophysics-Aeromagnetic, radiometric, and gravity data

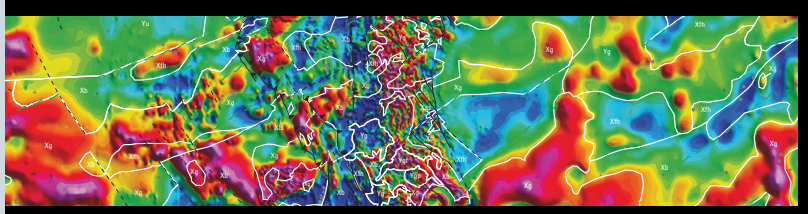

Geochemistry-Rocks, soils, and stream sediments

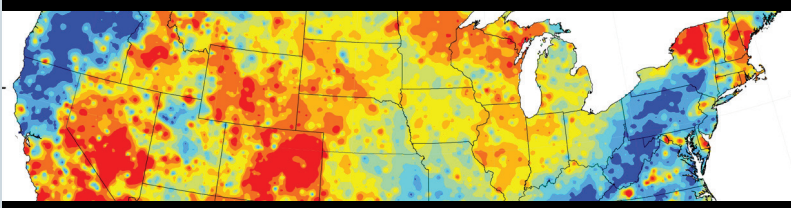

Mineral deposit databases-USMIN, MRDS, ARDF

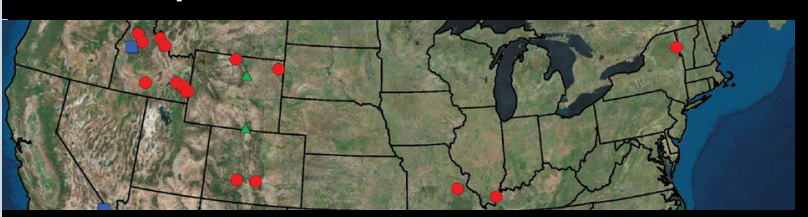

Coreholes-Geophysical logs and core samples

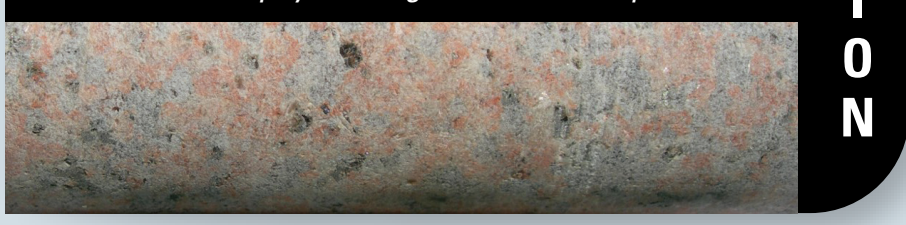

Applications
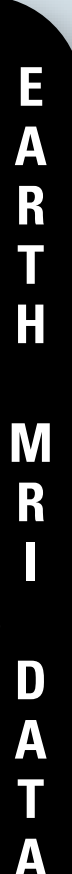

A

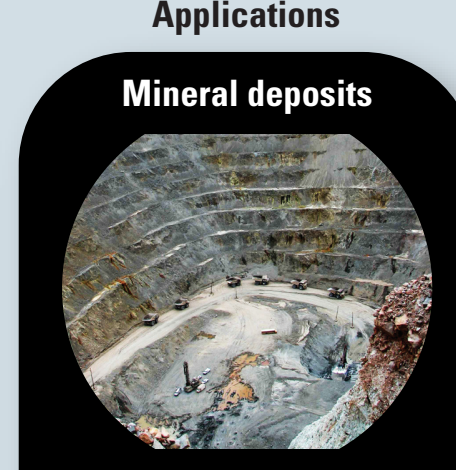

Groundwater resources

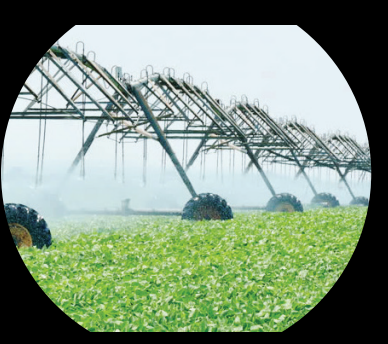

Energy

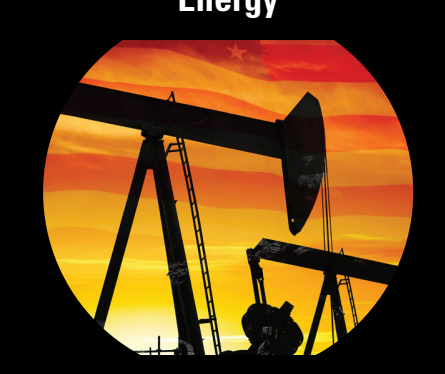

Natural hazards

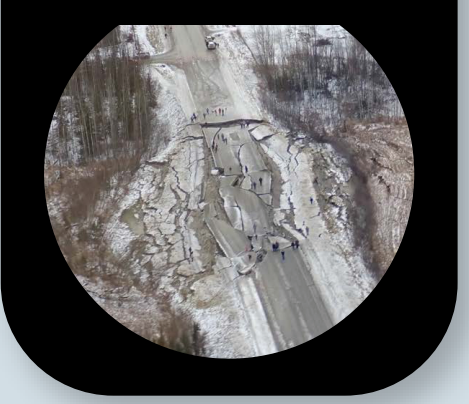

\section{References Cited}

ACIL Allen Consulting, 2015, Exploration incentive scheme economic impact study: Perth, Western Australia, Geological Survey of Western Australia, 78 p., accessed February 6, 2019, at http://dmpbookshop. eruditetechnologies.com.au/ product/exploration-incentivescheme-economic-impactstudy.do.

Duke, J.M., 2010, Government geoscience to support mineral exploration-Public policy rationale and impact (prepared for the Prospectors and Developers Association of Canada): National Geological Surveys Committee, 64 p., accessed February 8, 2019, at http://www.ngsccanada. com/files/Government Geoscience_Duke_PDAC. pdf.

Lederer, G.W., and McCullough, E.A., 2018, Meeting the mineral needs of the United States: Eos, v. 99, accessed February 7, 2019, at https://doi. org/10.1029/2018EO102177.

\section{-By Warren C. Day}

Figure 1. Planned applications for data acquired during the Earth Mapping Resources Initiative (Earth MRI). Images are from the U.S. Geological Survey (USGS). Sources for images in left column, from top to bottom: Topography: lidar image of Bingham Canyon open-pit mine, Utah (from USGS); Geology: State Geologic Map Compilation geodatabase (USGS Data Series 1052); Geophysics: aeromagnetic map of part of Colorado (USGS Open-File Report 01-0364); Geochemistry: soil geochemical landscapes of the conterminous United States (USGS Open-File Report 2014-1082); Mineral deposit databases: rare earth element production and resource sites in the United States (USMIN database); Coreholes: drill core of granite (from USGS). USGS databases: ARDF, Alaska Resource Data File; MRDS, Mineral Resources Data System; USMIN, USGS Mineral Deposit Database.

For additional information, please contact:

Mineral Resources Program U.S. Geological Survey 913 National Center 12201 Sunrise Valley Drive Reston, VA 20192
Email: Minerals@usgs.gov

Telephone: 703-648-6108

URL: https://www.usgs.gov/special-topic/earthmri
ISSN 2327-6916 (print) ISSN 2327-6932 (online) https://doi.org/10.3133/fs20193007 